\title{
Evaluasi sifat fisika, kimia dan kandungan logam berat di dalam nata de coco yang dibuat menggunakan sumber nitrogen dari NPK
}

\author{
Evaluation of physical, chemical and heavy metal content inside nata de coco made using \\ nitrogen source of NPK
}

\author{
Budi Santosa $^{1 *}$, Wirawan ${ }^{2)}$ \\ ${ }^{1,2}$ Program Studi Teknologi Industri Pertanian, Fakultas Pertanian, \\ Universitas Tribhuwana Tunggadewi, Jl. Telaga Warna, Tlogomas, Malang, Jawa Timur \\ "Email korespondensi: budi.unitri@gmail.com
}

Informasi Artikel:

Dikirim: 03/07/2021; disetujui: 25/08/2021; diterbitkan: 28/09/2021

\begin{abstract}
Nata de coco one of the beverage products produced from fermented coconut water using the help of starter Acetobacter xylinum. This product is very popular with people ranging from children to parents because the shape and texture resembles a gel. This study aims to evaluate the physical, chemical and heavy metal content in nata de coco made using nitrogen sources from NPK. The experimental plan used by The Complete Randomized Plan (RAL) is a single factor, the factor is the concentration of NPK consisting of 5 levels of $K 1=0.25 \%, K 2=0.5 \%, K 3=1 \%, K 4=1.5 \%, K 5=2 \%$. Each treatment was repeated 5 times and the total sample observed a total of 25 pieces. The observed observation parameters of nata thickness, nata weight, total fiber content of nata and metal residue content in nata include $\mathrm{Cu}, \mathrm{Zn}, \mathrm{Pb}$ metals, all of which are observed at the end of fermentation (the 14th day of fermentation). The initial parameters of the formation of nata are observed from the beginning of fermentation until the nata sheet is first formed. The results showed that nata de coco made using nitrogen source from NPK concentration of $0.1 \%$ has the best physical and chemical properties namely thickness of nata: $1,438 \mathrm{~cm}$, weight of nata: 309 grams, initial formation of nata 3.2 days and total fiber content of nata: 4.024\%. The use of NPK produces residues in the form of heavy metals $\mathrm{Cu}$ and $\mathrm{Zn}$ while pb heavy metals are undetectable. The higher the concentration of NPK given as a source of nitrogen, the higher the residues of heavy metals $\mathrm{Cu}$ and $\mathrm{Zn}$ in the nata de coco.
\end{abstract}

Keywords : nata de coco, nitrogen source, NPK, heavy metals

\begin{abstract}
ABSTRAK
Nata de coco salah satu produk minuman yang dihasilkan dari fermentasi air kelapa menggunakan bantuan starter Acetobacter xylinum. Produk ini sangat digemari masyarakat mulai anak-anak sampai orang tua karena bentuk dan teksturnya menyerupai gel. Penelitian ini bertujuan untuk mengevaluasi sifat fisika, kimia dan kandungan logam berat di dalam nata de coco yang dibuat menggunakan sumber nitrogen dari NPK. Rancangan percobaan yang digunakan Rancangan Acak Lengkap (RAL) faktor tunggal, faktornya yaitu konsentrasi NPK yang terdiri atas 5 level $\mathrm{K} 1=$ $0,25 \%, \mathrm{~K} 2=0,5 \%, \mathrm{~K} 3=1 \%, \mathrm{~K} 4=1,5 \%, \mathrm{~K} 5=2 \%$. Masing-masing perlakuan diulang 5 kali dan total sampel yang diamati sejumlah 25 buah. Parameter pengamatan yang diamati ketebalan nata, bobot nata, kadar serat total nata dan kandungan residu logam di dalam nata meliputi logam $\mathrm{Cu}, \mathrm{Zn}, \mathrm{Pb}$ ) yang semuanya diamati pada akhir fermentasi
\end{abstract}


(hari ke-14 fermentasi). Parameter awal terbentuknya nata diamati mulai permulaan fermentasi sampai lembaran nata pertama kali terbentuk. Hasil penelitian menunjukkan bahwa nata de coco yang dibuat menggunakan sumber nitrogen dari NPK konsentrasi $0,1 \%$ memiliki sifat fisika dan kimia terbaik yaitu ketebalan nata : $1,438 \mathrm{~cm}$, bobot nata : 309 gram, awal terbentuk nata 3, 2 hari dan kadar serat total nata : 4,024 \%. Penggunaan pupuk NPK menghasilkan residu berupa logam berat $\mathrm{Cu}$ dan $\mathrm{Zn}$ sementara logam berat $\mathrm{Pb}$ tidak terdeteksi. Semakin tinggi konsentrasi NPK yang diberikan sebagai sumber nitrogen maka semakin tinggi residu logam berat $\mathrm{Cu}$ dan $\mathrm{Zn}$ di dalam nata de coco.

Kata kunci : nata de coco, sumber nitrogen, NPK, logam berat

\section{PENDAHULUAN}

Sintesis nata de coco dilakukan dengan cara fermentasi dalam media air kelapa menggunakan starter dari bakteri Acetobacter xylinum (Santosa et.al, 2012; Santosa et.al, 2019a ; Santosa et.al, 2021). Nata de coco memiliki karakteristik berwarna putih, bentuk seperti gel, tekstur kenyal, kandungan serat tinggi, tidak mengandung kolesterol dan rendah kalori (Santosa et.al, 2019 ; Santosa et.al, 2020). Karakteristik ini yang membuat masyarakat menyukai produk nata karena selain rasanya enak juga bermanfaat untuk kesehatan terutama kesehatan pencernaan. Konsumsi nata de coco umumnya dibuat minuman dengan dicampur buah-buahan dan bahan-bahan lain. Terutama saat bulan Ramadhan tiba, produk ini banyak dicari masyarakat sebagai salah satu menu buka puasa.

Faktor-faktor yang mempengaruhi keberhasilan dalam pembuatan nata yaitu sumber karbon, sumber nitrogen, lama fermentasi dan starter. Faktor paling penting yang perlu diperhatikan dalam pembuatan nata yaitu sumber nitrogen. Produsen nata secara umum dalam pembuatannya menggunakan sumber nitrogen anorganik berupa urea atau NPK, hal ini dipilih karena harganya murah juga kualitas nata yang dihasilkan bagus ditinjau dari ketebalan nata dan bobot nata juga dari segi waktu bisa mempercepat proses terbentuknya nata.

NPK sebagai sumber nitrogen dalam pembuatan nata mengandung beberapa zat kimia selain nitrogen. Menurut (Wiyantoko et al., 2017; Balitbangtan, 2018) NPK mengandung unsur hara makro berupa nitrogen $(\mathrm{N})$, pospor $(\mathrm{P})$ dan kalium $(\mathrm{K})$ juga mengandung unsur hara mikro diantaranya tembaga $(\mathrm{Cu})$, Seng $(\mathrm{Zn})$, Mangan $(\mathrm{Mn})$, Kobal (Co) dan Besi (Fe). Bahan-bahan ini diduga meninggalkan residu logam berat pada nata de coco yang dihasilkan, karenanya perlu ada penelitian mengenai hal tersebut. Selama fermentasi pembuatan nata de coco, nitrogen yang terdapat pada NPK akan dimanfaatkan oleh Acetobacter xylinum sebagai sumber nitrogen $(\mathrm{N})$. Adapun bahanbahan selain nitrogen yang terdapat di dalam NPK tidak dimanfaatkan dan akan tertinggal di dalam material nata de coco yang terbentuk. Keberadaan residu ini menjadi hal penting yang harus diperhatikan terutama berkaitan dengan masalah keselamatan kesehatan pencernaan dan keamanan pangan. (Sudarmaji et al., 2006; Suksmerri, 2008; Agustina, 2014; Endrinaldi dan Asterina, 2014; Ardillah, 2016) menyatakan kandungan logam berat pada produk pangan akan mempengaruhi fungsi organ tubuh bila dikonsumsi secara berkesinambungan.

Pembuatan nata de coco yang bertujuan awal sebagai minuman sumber serat jangan sampai justru menyebabkan kerusakan fungsi organ khususnya organ pencernaan karena adanya residu logam berat yang tertinggal selama fermentasi berlangsung. Penelitian ini bertujuan untuk mengevaluasi sifat fisika, kimia dan kandungan logam berat di dalam nata de coco yang dibuat menggunakan sumber nitrogen dari NPK. 


\section{METODE}

\section{Bahan dan alat}

Bahan yang digunakan dalam penelitian yaitu air kelapa diambil dari buah kelapa varietas Sawarna (DSA) diperoleh dari kebun milik petani di Desa Dampit Kabupaten Malang. NPK diperoleh dari toko pertanian, asam asetat glasial (merck) diperoleh dari toko kimia Makmur Sejati dan sukrosa merk gulaku diperoleh dari toko swalayan serta biakan murni Acetobacter xylinum diperoleh dari Laboratorium Mikrobiologi Universitas Brawijaya Malang.

Peralatan yang digunakan yaitu panci dari bahan stainless stell, bak fermentasi dengan spesifikasi dari bahan plastik transparan merk maspion, ukuran bak panjang $11 \mathrm{~cm}$, lebar $11 \mathrm{~cm}$ dan tinggi bak $16 \mathrm{~cm}$, jangka sorong krisbow vernier caliper (KW0600071), gelas ukur kaca ukuran 100 ml merk pyrex, timbangan analitik merk shimadzu, timbangan ukuran $100 \mathrm{~kg}$, spektrofotometri Vis (Visible), kuvetmerk UV-Vis, pH meter merk Hanna, pipet volume kaca ukuran $10 \mathrm{ml}$ class A merk supertek.

\section{Pembiakan Acetobacter xylinum dalam starter}

Penelitian ini diawali dari pembutana starter, yang dimaksud starter yaitu strain Acetobacter xylinum dibiakkan ke dalam media. Pembuatan starter diawali dengan cara menginokulasikan strain murni ke dalam media air kelapa dari buah kelapa varietas Sawarna (DSA) yang sebelumnya sudah diperkaya dengan nutrisi berupa sukrosa dan NPK. pH media dibuat asam (kisaran angka 4) dengan cara menambahkan asam asetat glasial. Jumlah sel Acetobacter xylinum yang diinokulasi ke dalam media air kelapa sejumlah $2 \times 10^{7} \mathrm{sel} / \mathrm{ml}$. Perhitungan jumlah sel dilakukan secara langsung menggunakan metode haemocytometer (Oliveira et.al., 2015 and Sulistyani et.al., 2016). Starter diinkubasi sampai berumur 7 hari dimulai dari semenjak inokulsai.

\section{Pembuatan nata de coco}

Air kelapa dari varietas Sawarna (DSA) direbus pada suhu $100^{\circ} \mathrm{C}$ selama 15 menit. Kemudian ditambahkan sukrosa sebanyak $2 \%$ dan NPK sesuai perlakuan $0,025 \%, \quad 0,5 \%, \quad 0,1 \% \quad 0,15 \%, \quad 0,2 \%$ selanjutnya dididihkan lagi untuk proses homogenisasi antara air kelapa dengan nutrisi. Media kemudian dituang ke dalam bak fermentasi dan ditutup kertas perkamen dan dilapisi kain saring selanjutnya diikat menggunakan karet gelang.

Media didinginkan selama 12 jam setelah itu $\mathrm{pH}$ media dibuat menjadi 4 dengan menambahkan asam asetat glasial sebanyak $20 \mathrm{ml}$. Langkah terakhir starter Acetobacter xylinum diinokulasikan ke dalam media dan diinkubasi selama 14 hari.

\section{Pemanenan nata de coco}

Setelah 14 hari fermentasi, nata de coco dipanen dengan cara lembaran nata de coco diambil dari bak fermentasi selanjutnya dicuci pada air mengalir. Lembaran nata de coco kemudian dipotong-potong bentuk dadu ukuran 0,5 $\mathrm{cm}$ x 0,5 $\mathrm{cm}$ dan dicuci kembali. Potongan nata de coco direbus menggunakan air kapur konsentrasi $10 \%$ selama 1 jam untuk menghilangkan bau asam pada nata de coco. Selanjutnya nata de coco dicuci sampai bau kapurnya hilang dan direbus kembali menggunakan air bersih selama 1 jam.

\section{Rancangan percobaan}

Rancangan percobaan yang digunakan Rancangan Acak Lengkap faktor tunggal. Faktornya yaitu konsentrasi pupuk NPK terdiri atas 5 level yaitu $\mathrm{K} 1=0,025 \%, \mathrm{~K} 2=$ $0,5 \%, \mathrm{~K} 3=0,1 \%, \mathrm{~K} 4=0,15 \%$ dan $\mathrm{K} 5=$ $0,2 \%$. Masing-masing perlakuan diulang sebanyak 5 kali sehingga total sampel yang diamati sebanyak 36 buah.

\section{Pengamatan nata de coco}

Parameter pengamatan diamati pada hari ke 14 setelah pemanenan yaitu ketebalan nata (Hamad dan Kristiono, 2013), bobot nata (Gayathry, 2015), kadar serat total nata (Barry and Cleary, 2014), awal terbentuknya nata (Santosa, 2020), kandungan logam berat $(\mathrm{Cu}, \mathrm{Zn}$ dan $\mathrm{Pb})$ dengan metode AAS (Atomic Absorption Spectroscopy) (Parmiko et.al, 2014). 


\section{Analisis data}

Data yang diperoleh selama penelitian dianalisis menggunakan Analisys of Variance (ANOVA). Apabila terdapat beda nyata maka dilakukan uji lanjut dengan uji Beda Nyata Terkecil (BNT) pada $\alpha=1 \%$ (Hanafiah, 2012; Kumalaningsih, 2012).

\section{HASIL DAN PEMBAHASAN}

\section{Parameter kualitas nata de coco}

Hasil analisis sidik ragam ditunjukkan rata-rata nata de coco yang dihasilkan dari perlakuan konsentrasi pupuk NPK memiliki sifat sifat fisika dan kimia yang baik. Hal tersebut dapat dilihat pada tabel di bawah ini.

Tabel 1. Rata-rata kualitas nata de coco hasil perlakuan konsentrasi NPK yang berbeda

\begin{tabular}{lcccc}
\hline Perlakuan & $\begin{array}{c}\text { Ketebalan Nata } \\
(\mathrm{cm})\end{array}$ & $\begin{array}{c}\text { Bobot Nata } \\
(\text { gram })\end{array}$ & $\begin{array}{c}\text { Kadar Serat } \\
\text { Total Nata }(\%)\end{array}$ & $\begin{array}{c}\text { Awal } \\
\text { Terbentuk Nata } \\
(\text { Hari })\end{array}$ \\
\hline $0,025 \%$ & $0,624 \mathrm{a}$ & $96,6 \mathrm{a}$ & $1,172 \mathrm{a}$ & $4,8 \mathrm{~b}$ \\
$0,05 \%$ & $0,834 \mathrm{~b}$ & $107 \mathrm{~b}$ & $1,676 \mathrm{~b}$ & $4,8 \mathrm{~b}$ \\
$0,1 \%$ & $1,438 \mathrm{e}$ & $309 \mathrm{e}$ & $4,024 \mathrm{e}$ & $3,2 \mathrm{a}$ \\
$0,15 \%$ & $1,314 \mathrm{~d}$ & $253,4 \mathrm{~d}$ & $3,086 \mathrm{~d}$ & $3,8 \mathrm{ab}$ \\
$0,2 \%$ & $1,232 \mathrm{c}$ & $231,2 \mathrm{c}$ & $2,058 \mathrm{c}$ & $4,2 \mathrm{~b}$ \\
\hline \multicolumn{1}{c}{ BNT } & 0,028 & 3,535 & 0,07 & 0,8 \\
\hline
\end{tabular}

Keterangan: Angka-angka yang diikuti huruf yang sama pada kolom yang sama menunjukkan tidak beda nyata pada taraf BNT $1 \%$

Tabel di atas diperlihatkan sifat fisika kimia nata de coco berbeda nyata antar perlakuan. Sifat fisika kimia nata de coco yang dihasilkan dipengaruhi oleh konsentrasi NPK. Ketebalan, bobot dan kadar serat total nata de coco tertinggi terdapat pada perlakuan konsentrasi NPK $0,1 \%$. Sedangkan parameter awal terbentuknya nata tercepat pada 3,2 hari juga pada perlakuan konsentrasi NPK 0,1\%. Konsnetrasi NPK baik di bawah maupun di atas $0,1 \%$ menunjukkan rata-rata kualitasnya di bawah konsentrasi NPK 0,1\%.

Konsentrasi NPK 0,1\% merupakan konsentrasi sumber nitrogen optimal untuk menghasilkan nata de coco berkualitas. Semakin tinggi konsentrasi NPK justru menurunkan kualitas nata yang dihasilkan. Hal ini karena konsentrasi 0,1\% memberikan sumber nitrogen yang optimal sehingga Acetobacter xylinum bisa bekerja dengan baik sementara semakin tinggi konsentrasi NPK akan menurunkan aktifitas Acetobacter xylinum sehingga bakteri tidak bisa bekerja secara optimal dan hal ini sesuai dengan pendapat (Yanti et al., 2017) yang menyatakan semakin tinggi konsentrasi ammonium sulfat yang ditambahkan dapat meningkatkan kualitas nata de coco karena ammonium sulfat merupakan sumber nitrogen yang dapat meningkatkan aktifitas Acetobacter xylinum, namun konsentrasinya hanya sampai batas tertentu. Semakin tinggi konsentrasi ammonium sulfat yang ditambahkan justru menurunkan kualitas nata de coco yang dihasilkan karena konsentrasi ammonium sulfat yang berlebih menyebabkan aktifitas Acetobacter xylinum menurun. Sementara itu, semakin rendah konsentrasi NPK maka kualitas nata de coco yang dihasilkan rendah. Hal ini karena sumber nitrogen diperlukan untuk aktifitas Acetobacter xylinum, semakin rendah sumber nitrogen maka aktifitas Acetobacter xylinum semakin rendah juga.

Sumber nitrogen merupakan salah satu faktor penting dalam proses pembentukan nata de coco sehingga konsentrasi nitrogen yang tepat akan berpengaruh terhadap kualitas nata de coco yang dihasilkan. Sumber nitrogen dimanfaatkan oleh Acetobacter xylinum untuk mengaktifkan enzim ekstraselular yang pada akhirnya Acetobacter xylinum akan dapat bekerja secara optimal pada konsentrasi yang tepat. Hammad dan Kristiono (2013) mengatakan semakin besar penambahan konsentrasi ammonium sulfat maka kualitas nata yang dihasilkan semakin besar karena nitrogen 
diperlukan untuk aktifitas Acetobacter xylinum, semakin tinggi aktifitasnya maka biosintesis nata semakin baik tetapi penambahan konsentrasi hanya sampai batas tertentu karena penambahan konsentrasi ammonium sulfat semakin tinggi justru akan menurunkan kualitas nata yang dihasilkan karena kelebihan sumber nitrogen dapat menurunkan aktifitas Acetobacter xylinum.

Pada tabel 1 juga terlihat parameter ketebalan nata, bobot nata, kadar serat total nata dan awal terbentuknya nata mempunyai kaitan satu dengan yang lainnya. Kadar serat total tinggi akan meningkatkan ketebalan dan bobot nata karena pemberian konsentrasi
NPK yang optimal dapat mengaktifkan enzim ekstraselular Acetobacter xylinum, aktifitas Acetobacter xylinum yang tinggi menyebabkan semakin banyak serat selulosa nata yang terbentuk yang berdampak pada peningkatan ketebalan dan bobot nata.

\section{Parameter kandungan logam berat nata de} coco

Nata de coco yang dibuat menggunakan sumber nitrogen dari NPK dievaluasi dan diteliti kandungan logam di dalamnya. Hasil analisis sidik ragam dapat dilihat pada tabel di bawah ini:

Tabel 2. Rata-rata kandungan logam di dalam nata de coco hasil perlakuan konsentrasi NPK yang berbeda

\begin{tabular}{lccc}
\hline Perlakuan & $\begin{array}{c}\text { Kandungan Logam } \\
\mathrm{Cu}(\mathrm{ppm})\end{array}$ & $\begin{array}{c}\text { Kandungan Logam } \\
\text { Zn }(\mathrm{ppm})\end{array}$ & $\begin{array}{c}\text { Kandungan Logam } \mathrm{Pb} \\
(\mathrm{ppm})\end{array}$ \\
\hline $0,025 \%$ & $0,054 \mathrm{a}$ & $1,924 \mathrm{a}$ & Tidak terdeteksi \\
$0,05 \%$ & $0,068 \mathrm{~b}$ & $2,170 \mathrm{~b}$ & Tidak terdeteksi \\
$0,1 \%$ & $0,116 \mathrm{c}$ & $2,914 \mathrm{c}$ & Tidak terdeteksi \\
$0,15 \%$ & $0,254 \mathrm{~d}$ & $3,558 \mathrm{~d}$ & Tidak terdeteksi \\
$0,2 \%$ & $0,368 \mathrm{e}$ & $4,482 \mathrm{e}$ & Tidak terdeteksi \\
\hline \multicolumn{1}{c}{ BNT } & 0,013 & 0,02 & \\
\hline
\end{tabular}

Keterangan: Angka-angka yang diikuti huruf yang sama pada kolom yang sama menunjukkan tidak beda nyata pada taraf BNT $1 \%$

Tabel 2 diperlihatkan bahwa terdapat kandungan logam $\mathrm{Cu}$ dan $\mathrm{Zn}$ di dalam nata de coco yang dihasilkan. Logam $\mathrm{Pb}$ tidak terdeteksi di dalam nata de coco. Kandungan $\mathrm{Cu}$ tertinggi terdapat pada nata de coco yang menggunakan NPK dengan konsentrasi tertinggi $0,2 \%$. Kandungan $\mathrm{Cu}$ tertinggi sebesar 0,368 ppm. Kandungan logam Zn tertinggi yaitu sebesar 4,482 ppm juga terdapat pada perlakuan konsentrasi NPK tertinggi $0,2 \%$. Hal ini dikarenakan di dalam NPK mengandung unsur hara makro berupa Nitrogen (N), Pospor (P), Kalium (K) dan unsur hara mikro berupa tembaga $(\mathrm{Cu})$, Seng (Zn), Mangan (Mn), Kobal (Co) dan Besi $(\mathrm{Fe})$, dari semua unsur hara tersebut yang dimanfaatkan oleh Acetobacter xylinum dalam biosintesis nata de coco hanya unsur nitrogen sedangkan sisanya sebagai residu yang terikut dalam nata de coco. Berarti semakin tinggi konsentrasi NPK yang ditambahkan dalam media pembuatan nata de coco maka semakin tinggi residu logam $\mathrm{Cu}$ dan $\mathrm{Zn}$ yang ditinggalkan. (Parmiko et $a l$., 2014) mengatakan di dalam NPK mengandung unsur hara makro berupa unsur $\mathrm{N}, \mathrm{P}, \mathrm{K}$ dan unsur hara mikro berupa logam berat $\mathrm{Cu}$ dan $\mathrm{Zn}$, kedua logam berat ini apabila tersedia dalam jumlah yang berlebihan akan terserap oleh tanaman bukan sebagai unsur hara yang bermanfaat tetapi justru sebagai logam berat yang mencemari tanaman.

Kedua logam berat tersebut meskipun diperlukan tanaman tetapi apabila dalam jumlah yang berlebihan dapat menimbulkan racun bagi tanaman. Kedua logam berat ini akan lebih berbahaya apabila berada di dalam produk makanan seperti nata de coco karena dapat menimbulkan toksik di dalam tubuh manusia dan menyebabkan gangguan kesehatan. Hal ini sesuai dengan pendapat Agustina (2014) yang mengatakan bahan logam berat yang terdapat pada produk 
pangan dapat menyebabkan gangguan sistem syaraf, kerusakan otak, lumpuh, terhambat pertumbuhan, kerusakan ginjal, rapuh tulang dan kanker.

Pemerintah telah menentukan standar keamanan pangan terkait kandungan logam berat pada produk pangan yang dituangkan pada Standar Nasional Indonesia (SNI), dalam SNI tersebut disebutkan nata de coco tidak boleh mengandung bahan asing termasuk di dalamnya logam berat seperti $\mathrm{Cu}$ dan $\mathrm{Zn}$.

Tabel 3. Syarat mutu nata

\begin{tabular}{|c|c|c|c|}
\hline No & Jenis Uji & Satuan & Persyaratan \\
\hline 1 & $\mathrm{Bau}$ & - & Normal \\
\hline 2 & Rasa & - & Normal \\
\hline 3 & Warna & - & Normal \\
\hline 4 & Tekstur & - & Normal \\
\hline 5 & Bahan Asing & - & Tidak Boleh \\
\hline 6 & Bobot Tuntas (berat bersih+medium cair & $\%$ & Minimal 50 \\
\hline 7 & Jumlah Gula (dihitung sebagai sakarosa) & $\%$ & Minimal 15 \\
\hline 8 & Serat Makanan & $\%$ & Maksimal 4,5 \\
\hline
\end{tabular}

Sumber : SNI 01-4317-1996

Berdasarkan SNI tersebut nata de coco yang dihasilkan tidak memenuhi SNI sehingga penggunaan NPK sebagai sumber nitrogen dalam proses biosintesa nata de coco perlu dikaji ulang.

\section{KESIMPULAN}

Hasil penelitian disimpulkan bahwa nata de coco yang dibuat menggunakan sumber nitrogen dari NPK konsentrasi $0,1 \%$ memiliki sifat fisika dan kimia terbaik yaitu ketebalan nata : $1,438 \mathrm{~cm}$, bobot nata : 309 gram, awal terbentuk nata 3, 2 hari dan kadar serat total nata : 4,024\%. Penggunaan NPK menghasilkan residu berupa logam berat $\mathrm{Cu}$ dan $\mathrm{Zn}$ sementara logam berat $\mathrm{Pb}$ tidak terdeteksi. Semakin tinggi konsentrasi pupuk NPK yang diberikan sebagai sumber nitrogen maka semakin tinggi residu logam berat $\mathrm{Cu}$ dan $\mathrm{Zn}$ di dalam nata de coco. $\mathrm{s}$

\section{DAFTAR PUSTAKA}

Agustina, T. (2014). Kontaminasi logam berat pada makanan dan dampaknya pada kesehatan. Jurnal Teknobuga, 1(1), 53-65.

Badan Standarisasi Nasional. (1996). SNIO14317-1996 tentang nata dalam kemasan. Jakarta. Badan Standarisasi Nasional.
Ardillah, Y. (2016). Faktor risiko kandungan timbal di dalam darah. Jurnal Ilmu Kesehatan Masyarakat, 7(3), 150-155.

Balitbangtan. (2018). Syarat mutu pupuk anorganik dan organik. Kementerian Pertanian RI, hal.15-20.

Barry, V., \& Mc Cleary. (2014). Modification to aoac official mehods 2009.01 and 2011.25 to allow for minor overestimation of low moleculer weight soluble dietary fiber in samples containing starch. Journal of AOAC International, 3(97), 896-901.

Endrinaldi, \& Asterina. (2014). Pengaruh timbal $(\mathrm{Pb})$ terhadap kadar mda serum tikus putih jantan. Jurnal Kesehatan Andalas, 3(3), 531-535.

Gayathry, G. (2015). Production of nata de coco a natural dietary fibre product from mature coconut water using gluconacetobacter xylinum. International Journal Food Fermentation Technology, 5(2), 231235.

Hamad, A., \& Kristiono. (2013). Pengaruh penambahan sumber nitrogen terhadap hasil fermentasi nata de coco. Jurnal Momentum, 9(1), 62-65.

Hanafiah, K.A. (2012). Rancangan percobaan (teori dan aplikasi). Jakarta: Rajawali Press. 
Kumalaningsih, S. (2012). Metodologi penelitian (kupas tuntas cara mencapai tujuan). Malang: UB Press.

Oliveira, P.M., Brosnan, B., Furey, A., Coffey, A., Zannini, E., \& Arendt, E.K. (2015). Lactic acid bacteria bioprotection applied to the malting process. part i : strain characterization and indentification of antifungal compounds. Journal of Food Control, (51), 433-443.

Parmiko, I.P.M., Siaka, I.M., \& Suarya, P. (2014). Kandungan logam $\mathrm{Cu}$ dan $\mathrm{Zn}$ dalam tanah dan pupuk serta bioavailabilitasnya dalam tanah pertanian di daerah bedugul. Jurnal Kimia, 8(1), 91 -96.

Santosa, B., Ahmadi, Kgs., \& Taeque, D. (2012). Dextrin concentration and carboxy methyl cellulosa $(\mathrm{cmc})$ in making of fiber-rich instant baverage from nata de coco. International Journal of Science and Technology, 1(1), 6-11.

Santosa, B., Tantalu, L., \& Sugiarti, U. $\left(2019^{a}\right)$. Penambahan ekstrak kulit buah naga pada pengembangan produk nata de coco berantioksidan. Jurnal Teknologi Pangan, 10(1), 1-8.

Santosa, B., Wirawan, \& Muljawan, R.E. $\left(2019^{b}\right)$. Pemanfaatan molase sebagai sumber karbon alternatif dalam pembuatan nata de coco. Jurnal Teknologi Pangan, 10(2), 1-9.

Santosa, B., Wignyanto, Hidayat, N., \& Sucipto. (2020). The quality of nata de coco from sawarna and mapanget coconut varieties to the time of storing coconut water. Food Research, 4(4), 957-963.

Santosa, B. (2020). Proses pembuatan bubuk probiotik lactobacillus plantarum menggunakan filler bacterial cellulose. Universitas Brawijaya. Malang. Disertasi.

Santosa, B., Rozana, \& Astutik. (2021). Pemanfaatan sumber nitrogen organik dalam pembuatan nata de coco. Jurnal Teknologi Pangan, 12(1), 55-63.
Sudarmaji, Mukono, J., \& Corie, I.P. (2006). Toksikologi logam berat b3 dan dampaknya terhadap kesehatan. Jurnal Kesehatan Lingkungan, 2(2), 129 142.

Suksmerri. (2008). Dampak pencemaran logam timah hitam $(\mathrm{Pb})$ terhadap kesehatan. Jurnal Kesehatan Masyarakat, II(2), 200-202.

Sulistyani, H., Fujita, M., Miyakawa, H., \& Nakazawa, F. (2016). Effect of roselle calyx extract on in vitro viability and biofilm formation ability of oral pathogenic bacteria. Asian Pacific Journal of Tropical Medicine, 9(2), 119-124.

Wiyantoko, B., Kurniawati, P., \& Purbaningtias, T.E. (2017). Pengujian nitrogen total, kandungan air dan cemaran logam timbal pada pupuk anorganik nitrogen phospor kalium (npk) padat. Jurnal Sains dan Teknologi, 6(1), 51-60.

Yanti, N.A., Ahmad, S.W., Tryaswaty, D., \& Nurhana, A. (2017). Pengaruh penambahan gula dan nitrogen pada produksi nata de coco. Jurnal Biowallacea, 4(1), 540-545. 